\title{
Innovation, exports and productivity
}

\author{
Bruno Cassiman ${ }^{\mathrm{a}, *}$, Elena Golovko ${ }^{\mathrm{b}}$, Ester Martínez-Ros $^{\mathrm{c}}$ \\ a IESE Business School, K.U. Leuven and CEPR, Spain \\ b Tilburg University, CIR and CentER, Netherlands \\ ' Universidad Carlos III, Madrid, Spain
}

\section{A R T I C L E I N F O}

Available online 11 March 2010

\section{Jel Classification:}

D21

F23

L25

032

Keywords:

Innovation

Exports

Productivity

\section{A B S T R A C T}

We argue that the positive association found between firm productivity and exports in the literature relates to the firm's innovation decisions. Using a panel of Spanish manufacturing firms we find strong evidence that product innovation and not process innovation affects productivity and induces small non exporting firms to enter the export market.

\section{Introduction}

Firms are born, make decisions, thrive or they die. This dynamic process of firm lifecycles generates a tremendous amount of heterogeneity among firms not only across industries, but more interestingly, also within industries (Bartelsman and Doms, 2000).

Most of the theoretical models on industry dynamics assume that firms are born with an inherent ability, their productivity. Efficient firms survive and grow in the market, while inefficient firms, with productivity below a certain threshold, decline and fail (Jovanovic, 1982; Hopenhayn, 1992). These models, however, assume that the productivity distribution across firms is exogenous to firms, thus relating firm survival to luck of draw. Firms with low productivity exit, while "lucky" firms with high productivity survive and continue growing. Little room is left for firm decisions.

While theoretically such heterogeneity and dynamics is difficult to handle, empirically it provides a wealth of interesting observations. Nevertheless, we know very little about the connection between individual firm decisions and their dynamic consequences. One of the basic empirical facts related to productivity is a strong positive association between productivity and exporting activity at the firm level. Most of the studies explain this pattern by self selection of more efficient firms into the export market (Clerides et al., 1998; Bernard and Jensen, 1999; Delgado et al., 2002), confirming the sunk cost hypothesis that only those firms who are efficient enough to bear entry costs and intense competition of the export market will start

\footnotetext{
* Corresponding author.

E-mail address: BCassiman@iese.edu (B. Cassiman).
}

exporting. This suggests that a closer examination of prior firm decisions might be needed to understand this important selection.

In this paper, we present some findings developed in full in Cassiman and Martinez Ros (2007) and Cassiman and Golovko (2009) where we take a first step towards explaining the observed productivity export link. Following Lileeva and Trefler (2007) we argue that a potential underlying mechanism for the selection of more productive firms into exporting is related to the firm's prior investment decisions. Furthermore, exporting enhances the return to such investment decisions and as such is complementary to the productivity enhancing investment decisions. In particular, we examine the effect of innovation activity, as an investment decision which has been suggested to enhance productivity.

The findings of the empirical studies show that one of the important sources of the productivity heterogeneity at the firm level is related to R\&D and innovation activities (see Griliches, 1998). Moreover, the recent productivity literature has found evidence suggesting that firm specific demand variations, rather than technical efficiency, are the dominant factor in determining firm survival and positively influence measured productivity (Foster et al., 2008). This suggests that different innovation activities might affect productivity differentially. Product innovation should relate more to firm specific demand variations where as process innovation is expected to affect technical efficiency. As a result product innovation is expected to affect measured productivity more and, consequently, entry into exporting.

At the same time, R\&D and innovation activities seem to play an important role in explaining a firm's decision to export and export volumes. Several empirical studies have linked innovation to exporting (e.g., Basile, 2001; Bernard and Jensen, 2004). Vernon (1966) in his very influential paper on the internationalization of US business 
Table 1

Distribution of firms by year, 1991-1998.

\begin{tabular}{|c|c|c|c|c|c|c|c|c|c|c|}
\hline & 1990 & 1991 & 1992 & 1993 & 1994 & 1995 & 1996 & 1997 & 1998 & Total \\
\hline$\%$ of exporting firms & $\begin{array}{l}0.32 \\
(0.46)\end{array}$ & $\begin{array}{l}0.33 \\
(0.46)\end{array}$ & $\begin{array}{l}0.37 \\
(0.48)\end{array}$ & $\begin{array}{l}0.38 \\
(0.48)\end{array}$ & $\begin{array}{l}0.42 \\
(0.49)\end{array}$ & $\begin{array}{l}0.47 \\
(0.49)\end{array}$ & $\begin{array}{l}0.47 \\
(0.49)\end{array}$ & $\begin{array}{l}0.51 \\
(0.50)\end{array}$ & $\begin{array}{l}0.52 \\
(0.50)\end{array}$ & $\begin{array}{l}0.43 \\
(0.49)\end{array}$ \\
\hline$\%$ of firms with product innovation & $\begin{array}{l}0.13 \\
(0.34)\end{array}$ & $\begin{array}{l}0.20 \\
(0.40)\end{array}$ & $\begin{array}{l}0.22 \\
(0.41)\end{array}$ & $\begin{array}{l}0.21 \\
(0.41)\end{array}$ & $\begin{array}{l}0.21 \\
(0.41)\end{array}$ & $\begin{array}{l}0.22 \\
(0.41)\end{array}$ & $\begin{array}{l}0.20 \\
(0.40)\end{array}$ & $\begin{array}{l}0.22 \\
(0.41)\end{array}$ & $\begin{array}{l}0.21 \\
(0.40)\end{array}$ & $\begin{array}{l}0.21 \\
(0.40)\end{array}$ \\
\hline$\%$ of firms with process innovation & $\begin{array}{l}0.12 \\
(0.32)\end{array}$ & $\begin{array}{l}0.27 \\
(0.44)\end{array}$ & $\begin{array}{l}0.25 \\
(0.43)\end{array}$ & $\begin{array}{l}0.27 \\
(0.44)\end{array}$ & $\begin{array}{l}0.28 \\
(0.45)\end{array}$ & $\begin{array}{l}0.25 \\
(0.43)\end{array}$ & $\begin{array}{l}0.24 \\
(0.42)\end{array}$ & $\begin{array}{l}0.28 \\
(0.45)\end{array}$ & $\begin{array}{l}0.30 \\
(0.46)\end{array}$ & $\begin{array}{l}0.27 \\
(0.44)\end{array}$ \\
\hline$\%$ of firms with no innovation & $\begin{array}{l}0.75 \\
(0.46)\end{array}$ & $\begin{array}{l}0.63 \\
(0.48)\end{array}$ & $\begin{array}{l}0.64 \\
(0.48)\end{array}$ & $\begin{array}{l}0.62 \\
(0.48)\end{array}$ & $\begin{array}{l}0.62 \\
(0.48)\end{array}$ & $\begin{array}{l}0.63 \\
(0.48)\end{array}$ & $\begin{array}{l}0.64 \\
(0.48)\end{array}$ & $\begin{array}{l}0.60 \\
(0.48)\end{array}$ & $\begin{array}{l}0.59 \\
(0.49)\end{array}$ & $\begin{array}{l}0.58 \\
(0.49)\end{array}$ \\
\hline Number of observations & 969 & 1011 & 1036 & 1055 & 1039 & 970 & 1029 & 1183 & 1079 & 9371 \\
\hline
\end{tabular}

hypothesized the evolution from product innovation in the home market to exporting as the initial stage in the internationalization process. Young firms possess a new product in the early phase of the product lifecycle based on proprietary knowledge. As the domestic market is limited in the early innovation stage the firm moves to enter into the export market to exploit their market power (Hirsch and Bijaoui, 1985). Iacovone and Javorcik (2008) and Kugler and Verhoogen (2008) show that firms' exports are higher priced which suggest that the higher quality products the good apples are being exported.

Following the product lifecycle logic we, therefore, argue that successful product innovation will induce the firm to enter the export market. A potential underlying mechanism for the selection of more productive firms into the export market is, therefore, that successful (product) innovation improves the firm's productivity, and, hence, these more productive firms select into the export market.

In this study, we are interested in evaluating the effect of innovation on the export productivity association. We will go about this in two steps. First we will relate innovation, productivity and exports at the firm level comparing productivity distributions of firms making different decisions. In a second step we take a more reduced form approach of relating innovation decisions of firms directly to their export decisions, abstracting from the intermediate productivity effect.

\subsection{Empirical strategy}

\subsubsection{Data}

We test our hypotheses about the relation between innovation, productivity and the export decision of firms on a large representative sample of Spanish manufacturing firms. The data come from the Spanish ESEE survey. ${ }^{1}$ We use a panel of small and medium sized firms running from 1990 until 1998, i.e. those firms that have 200 or less employees. Our sample includes 1478 firms in 1990 and 1256 firms in 1998 from 20 distinctive industries. Due to missing values the resulting sample is an unbalanced panel with about 9300 firm year observations.

This dataset provides an appropriate setting to test the relationship between exports, innovation, and productivity. First, it allows tracing the firms and their export and innovation decisions over time. Second, exporting firms constitute a large proportion in the sample and shows considerable variation over time. Third, there are very few firms (less than $0.3 \%$ of the sample) with foreign direct investment. In this way, we are able to focus on export, without confounding effects of other interna tionalization strategies. Finally, during 19901998 Spain has gone through the entire business cycle. In 1990 there was growth in the economy, followed by a sharp recession in 1993, and a recovery during the last years

\footnotetext{
${ }^{1}$ The data that are used in this study come from a survey (Encuesta Sobre Estrategias Empresariales, ESEE) of Spanish manufacturing firms started in 1990 with data collected annually. The project was conducted by the Fundación Empresa Pública with financial support of the Spanish Ministry of Science and Technology. The sample includes the population of Spanish manufacturing firms with 200 or more employees. It also contains a stratified sample of small firms comprising $4 \%$ of the population of small firms with more than 10 and less than 200 employees. Previous research has used the same dataset as it is representative for the Spanish manufacturing industry over this period (Delgado et al., 2002 Campa, 2004; Huergo and Jaumandreu, 2004; Salomon and Shaver, 2005; among others).
}

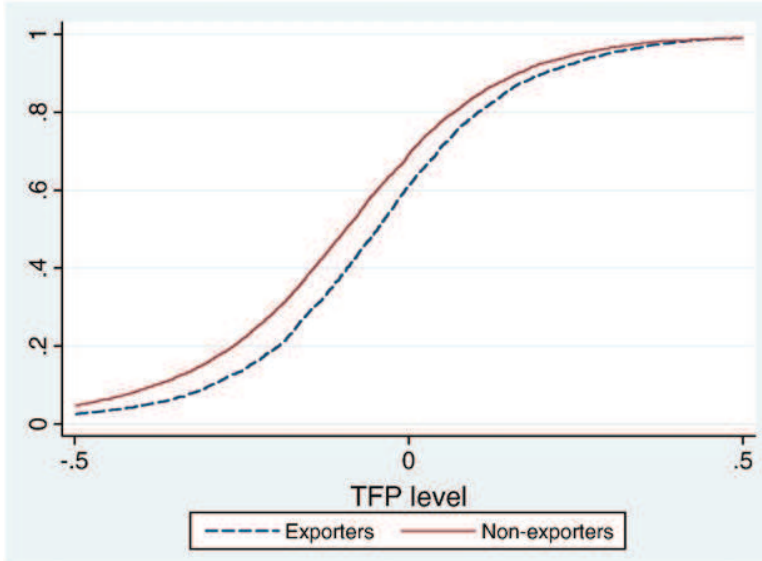

Fig. 1. Cumulative distribution of TFP levels, 1991-1998. Exporting versus non-exporting firms.

of the sample period (Shaver, 2007). Such variance can be usefully exploited to examine the productivity dynamics during 19901998.

The survey contains detailed information for every year on exporting and innovation activities, reporting among other questions information on export status and on product and process innovation carried out by a firm. We define exporters as firms exporting, i.e. with positive sales outside of Spain, in the current year. For innovation activity we distinguish between innovating in product and in process, using two dummies that indicate whether a firm carried out a product or a process innovation, respectively. Furthermore, we employ a dummy variable that indicates whether a firm has performed any innovation activity (either product or process). We report the results for one year lagged innovation variables. ${ }^{2}$

Table 1 summarizes the export and innovation status of the firms in the final sample. Approximately $43 \%$ of the SMEs are exporters, with the proportion of exporting firms increasing from 32\% in 1990 to $52 \%$ in 1998 . About $21 \%$ of firms in the sample report product innovation activities, ranging from $13 \%$ in 1990 to $21 \%$ in 1998 . About $27 \%$ of firms have engaged in process innovation, with the proportion ranging from $12 \%$ in 1990 to $30 \%$ in 1998 .

\subsubsection{Innovation productivity exports}

Innovating firms show higher productivity levels and grow faster than non innovators. At the same time, these firms are more likely to become exporters compared to non innovating firms. In the empirical setting, omitting an innovation variable from the analysis may lead to the overestimation of the productivity exports association. Thus, we

\footnotetext{
${ }^{2}$ As innovation does show some persistence we did experiment with various lag specifications. Our basic result is robust to these alternative specifications. The ESEE survey uses the following definition of product innovation: whether a firm obtained product innovation in a given year - new products, or products with new features that are different from those that a firm produced in the previous years. Process innovation is defined as an important modification in the production process, such as introduction of new machinery, introduction of new methods of production organization, or both.
} 

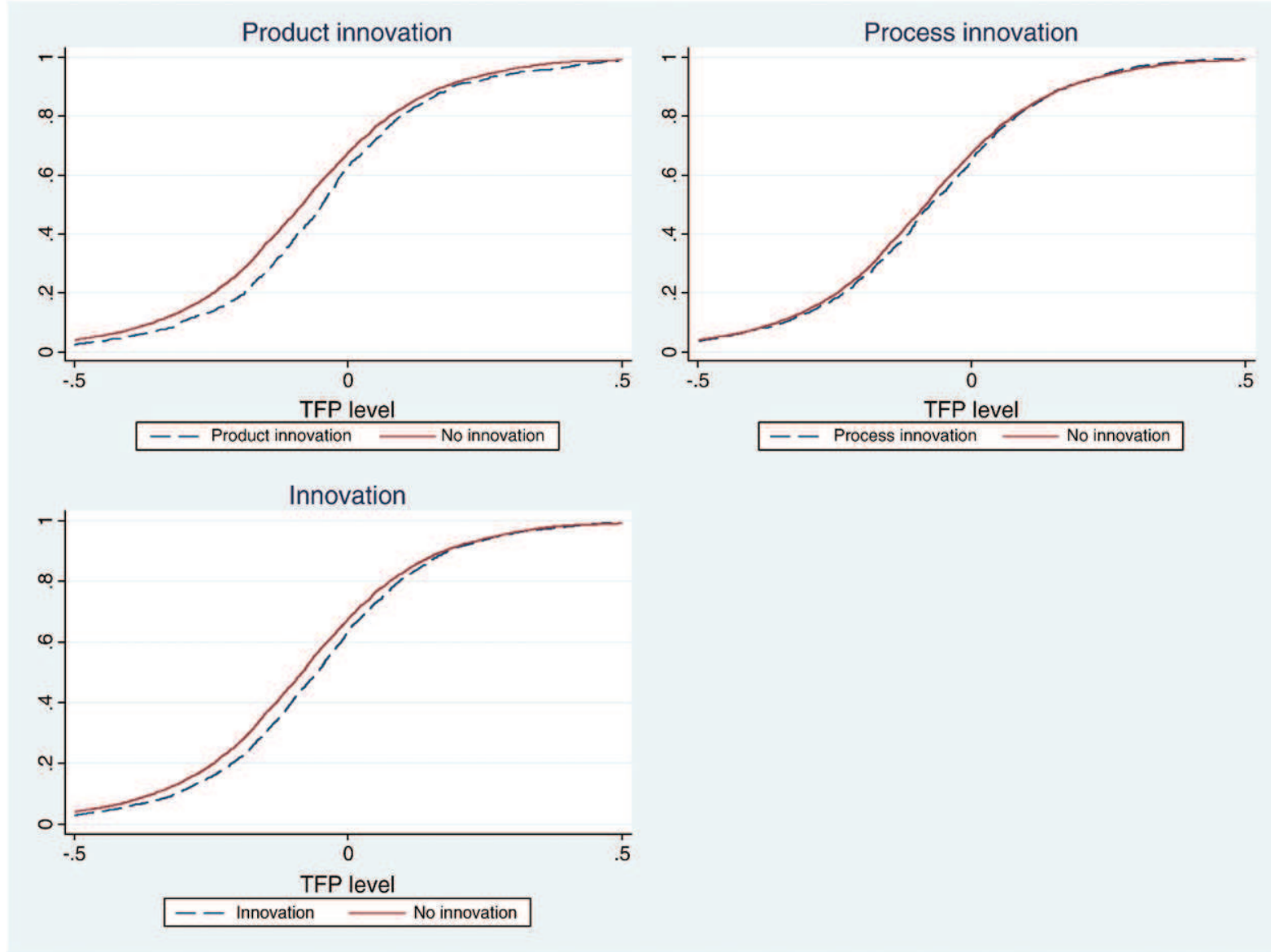

Fig. 2. Cumulative distribution of TFP levels, 1991-1998. Innovating versus non-innovating firms.

expect the correlation between exports and productivity to weaken once we take innovation status of a firm into account. That is, we expect to observe less variation in productivity between exporters and non exporters for the firms that were innovation active.

To test the proposed relationship between innovation, exports and productivity, we apply a recently developed methodology that allows testing for the differences in distributions. This methodology employs a Kolmogorov Smirnov equality of distributions test, used recently in Delgado et al. (2002). ${ }^{3}$ We compare the productivity distributions of different samples of firms, e.g. exporters and non exporters. If the productivity distributions of exporters stochastically dominate the productivity distributions of non exporters this implies that exporters tend to be more productive than non exporters.

As export and innovation decisions involve a lot of uncertainty, such a methodology provides an interesting window on the stochastic nature of the outcomes. Rather than worry about what happens to the average of a population of firms when making a particular investment as is the case of the classical regression analysis, we want to learn something about the stochastic outcome of these decisions and their overall distribution. Moreover, distribution comparison does not make any specific assumption about the form of the interdependence between productivity, innovation, and exports, unlike regression analysis.

We start by reproducing the positive association between productivity and export status for our sample, by testing the difference

\footnotetext{
3 The methodology is based on the concept of first-order stochastic dominance. In order to show that one distribution stochastically dominates the other, we have to demonstrate that: 1) the null hypothesis for the two-sided test for the equality of distributions is rejected (i.e. the distributions are significantly different) and 2) the null hypothesis for one-sided test for the equality of distributions cannot be rejected (i.e. one distribution is to the right of the other).
}

in productivity between exporting and non exporting firms. We proceed by comparing the productivity levels of innovating versus non innovating firms in order to show that innovation activity correlates with future firm productivity. Finally, we test for the differences in productivity of exporters and non exporters accounting for firm innovation status in the previous time periods.

To test the differences in the productivity distributions, we employ a Kolmogorov Smirnov equality of distributions test, used recently in Delgado et al. (2002), see Cassiman and Golovko (2009).

Total factor productivity (TFP) our productivity measure is constructed as an index of TFP using a multilateral index developed by Caves et al. (1982) and extended by Good et al. (1997). ${ }^{4}$ The main advantage of this productivity measure is that the parameters of the production function need not be estimated to compute productivity (Delgado et al., 2002). The index is computed as each firm's output and input deviations from a reference firm. The reference firm is a hypothetical average firm that varies across industries. That is, each firm's output, inputs and productivity for each year are measured relative to this hypothetical firm in the same industry. Firms with positive (negative) residuals are relatively more (less) productive. ${ }^{5}$

Figs. 13 give the graphical representation of the TFP cumulative distribution functions for different subsamples.

\footnotetext{
${ }^{4}$ This productivity measure has been used in Aw et al. (2001, 2007), Delgado et al. (2002). The TFP index compares productivity levels across firms in a given year and across different years, thus it is well suited for firm-level panel data and for the distribution comparison methodology. Moreover, the TFP index has an advantage of being a non-parametric approximation to a general production function.

${ }^{5}$ Our productivity measure is subject to usual criticism on productivity metrics related to the availability of the data, e.g. using a revenue-based output measure. However, despite these concerns, research finds little sensitivity of the results related to the specific productivity measurement choice (Van Biesebroeck, 2007; Syverson, 2010).
} 




Fig. 3. Cumulative distribution of TFP levels, 1991-1998. Exporting versus non-exporting firms conditional on previous innovation status.

The distribution of performers (exporters or innovators) lies to the right of the distribution of non performers, which suggests first order stochastic dominance. The exception is the process innovation case (Fig. 2), for which TFP level distributions of innovating and non innovating firms seem to coincide, which suggests that there are no significant differences in productivity between firms with process innovation and firms with no innovation. ${ }^{6}$ Fig. 3 compares the productivity distributions of exporters and non exporters in the groups of innovators and non innovators for different types of innovation. For the non innovating firms, the TFP distribution of exporters is clearly to the right of that of non exporters, which points towards stochastic dominance. In the group of innovating firms the TFP level distributions seem to be closer to each other, especially for the product innovation case. Overall, the visual comparison of the TFP level distributions shows that the productivity distribution of exporters dominates that of non exporters. For innovating firms, however, the difference is less pronounced for the product innovation case, suggesting the existence of a moderating effect of (product) innovation activity on the productivity and export relation. The distribution comparison tests (Kolmogorov Smirnov tests) confirm that these differences in the case of product innovators are actually not significant (see Cassiman and Golovko, 2009). This is suggestive of the

\footnotetext{
${ }^{6}$ This result needs careful interpretation. Process innovation usually involves changes in the production process aimed at improving production efficiency, thus presumably having a direct effect on the firm's productivity. We do not observe such an effect in our data. The possible explanation could be that very often process innovation is incorporated in the capital investment, as suggested by Crespi et al. (2006): process innovation "is a combination of advanced capital investment and process organizational change." As we already control for capital investment in our productivity measure (TFP), we should not expect a significant effect of process innovation on productivity measured as total factor productivity.
}

fact that the relation between productivity and exports runs through product innovation as firms with a product innovation become more productive.

\subsubsection{Innovation and export decision}

Next, we take a reduced form approach to this issue in trying to relate the export market entry decision of the firm to other prior firm level decisions and outcomes, in particular innovation decisions. In this context the export no export dichotomy allows us to observe the firms that do not export, unlike the new firm entering a market for which often times no prior information is available.

Turning to the link between innovation and exports a key variable to control for is past export behavior. As shown by Roberts and Tybout (1997) the past export status of the firm is a key explanatory variable capturing the sunk cost effect of previous investments in exporting. Table 2 shows the transition probabilities for the different states of past to present export status. More than $90 \%$ of the firms remain in the same state: exporters continue to export and non exporters continue as non exporters. About $8.8 \%$ of non exporters become exporters. We want to understand what affects this transition from non exporter to exporter (and vice versa) and conjecture that (product) innovation

Table 2

Transition probabilities exports.

\begin{tabular}{lllll}
\hline & & \multicolumn{2}{l}{ Export $_{\mathrm{t}}$} & \\
\cline { 3 - 4 } & & 0 & 1 & Total \\
\hline Export $_{\mathrm{t}-1}$ & 0 & $3077(91.2 \%)$ & $295(8.8 \%)$ & $3372(100 \%)$ \\
& 1 & $184(7.2 \%)$ & $2384(92.8 \%)$ & $2568(100 \%)$ \\
& Total & 3261 & 2679 & 5940 \\
\hline
\end{tabular}


Table 3

Transition probabilities conditional on product or process innovations.

\begin{tabular}{|c|c|c|c|c|}
\hline & & & \multicolumn{2}{|l|}{ Export $_{\mathrm{t}}$} \\
\hline & & & 0 & 1 \\
\hline \multirow[t]{12}{*}{ Export $_{t-1}$} & 0 & Product & & \\
\hline & & 0 & $3592(91.9 \%)$ & $318(8.1 \%)$ \\
\hline & & 1 & $536(86.9 \% .0 \%)$ & $81(13.1 \%)$ \\
\hline & & Process & & \\
\hline & & 0 & $3305(91.8 \% .6 \%)$ & $297(8.2 \%)$ \\
\hline & & 1 & $823(89.0 \%)$ & $102(11.0 \%)$ \\
\hline & 1 & Product & & \\
\hline & & 0 & $201(8.9 \%)$ & 2077 (91.1\%) \\
\hline & & 1 & $51(5.1 \%)$ & $955(94.9 \%)$ \\
\hline & & Process & & \\
\hline & & 0 & $188(8.4 \%)$ & 2067 (91.6\%) \\
\hline & & 1 & $64(6.3 \%)$ & $965(93.7 \%)$ \\
\hline
\end{tabular}

might jump start firms into exporting. Table 3 examines the effect of product and process innovation on the transition probability from non exporter to exporter. In our sample $13.1 \%$ of product innovators make the transition, while $11 \%$ of the process innovators switch from non exporting to exporting. This implies that product innovation improves the probability of an average firm entering in the export market from $8.8 \%$ to $13.1 \%$, i.e. an increase in the likelihood of entering the export market by $49 \%((13-8) / 8)$. Interestingly product innovation also seems to affect the reverse direction from exporter to non exporter. Exporters that have a product innovation are less likely to regress towards being a non exporter. These descriptive statistics suggest that innovation in particular product innovation affects the decision to start exporting. Cassiman and Martinez Ros (2007) try to carefully corroborate these findings controlling for other elements and the endogeneity of innovation and find a very strong effect of product innovation on the decision to export, but no effect of process innovation on the same decision.

\subsection{Conclusion}

We find strong evidence that product innovation and not process innovation induces small non exporting firms to enter the export market. Such finding has important policy implications for the relative importance of export promotion policies versus innovation promo tion policies to simulate productivity growth in the economy. Clearly, the fact that the more productive firms select into the export market already invalidated many arguments in favour of export promotion activities. Nevertheless, as the firm decisions driving these produc tivity effects were not explicated, alternative policies were not advanced. Our results suggest that a stronger focus on innovation should provide a more productive investment for policy makers.

\section{Acknowledgements}

Bruno Cassiman is a research fellow of the SP SP Research Center at IESE Business School and acknowledges partial financial support from the Spanish Ministry of Science and Innovation through project no. ECO2009 13169 and the Catalan Government Grant no. 2009 SGR919. Ester Martínez Ros acknowledges partial financial support from the Spanish Ministry of Science and Education through project no. SEC2006 03963/001 and ECO2009 08308.

\section{References}

Aw, B.Y., Chen, X., Roberts, M.J., 2001. Firm-Level Evidence on Productivity Differentials and Turnover in Taiwanese Manufacturing. Journal of Development Economics 66 (1), 51-86.

Aw, B.Y., Roberts, M.J., Winston, T., 2007. Export market participation, investments in R\&D and worker training, and the evolution of firm productivity. The World Economy 30 (1), 83-104.

Bartelsman, E.J., Doms, M., 2000. Understanding productivity: lessons from longitudinal microdata. Journal of Economic Literature 38 (3), 569-594.

Basile, R., 2001. Export behaviour of Italian manufacturing firms over the nineties: the role of innovation. Research Policy 30 (8), 1185-1201.

Bernard, A., Jensen, J., 1999. Exceptional exporter performance: cause, effect or both? Journal of International Economics 47 (1), 1-25.

Bernard, A., Jensen, J., 2004. Why some firms export. The Review of Economics and Statistics 86 (2), 561-569.

Campa, J.M., 2004. Exchange rates and trade: how important is hysteresis in trade? European Economic Review 48 (3), 527-548.

Cassiman, B. \& E. Golovko, 2009, Innovation and Internationalization, IESE working paper, mimeo.

Cassiman, B., \& Martinez-Ros, E. 2007. Product Innovation and Exports: Evidence from Spanish Manufacturing. IESE working paper, mimeo.

Caves, D., Christensen, L., Diewert, E., 1982. Output, input, and productivity using superlative index numbers. Economic Journal 92 (365), 73-86.

Clerides, S., Lach, S., Tybout, J., 1998. Is learning by exporting important? Microdynamic evidence from Colombia, Mexico, and Morocco. The Quarterly Journal of Economics 113 (3), 903-947.

Crespi, G., Criscuolo, C., Haskel, J., 2006. Information technology, organisational change and productivity growth: evidence from UK firms. Working Paper 558. Queen Mary, University of London.

Delgado, M., Farinas, J., Ruano, S., 2002. Firm productivity and export markets: a nonparametric approach. Journal of International Economics 57 (2), 397-422.

Foster, L., Haltiwanger, J., Syverson, C., 2008. Reallocation, firm turnover, and efficiency: selection on productivity or profitability? American Economic Review 98 (1), 394-425.

Good, D., Nadiri, M., Sickles, R., 1997. Index number and factor demand approaches to the estimation of productivity. In: Pesaran, M., Schmidt, P. (Eds.), Handbook of Applied Econometrics. : Microeconometrics, Vol II. Basil Blackwell.

Griliches, Z., 1998. R\&D and productivity: the econometric evidence. The University of Chicago Press, Chicago.

Hirsch, S., Bijaoui, I., 1985. R\&D intensity and export performance: a micro view. Weltwirtschaftliches Archiv 121 (2), 238-251.

Hopenhayn, H., 1992. Entry, exit and firm dynamics in long run equilibrium. Econometrica 60 (5), 1127-1150.

Huergo, E., Jaumandreu, J., 2004. Firms' age, process innovation and productivity growth. International Journal of Industrial Organization 22, 541-559.

Iacovone, L., \& Javorcik, B. 2008. Shipping Good Tequila Out: Investment, Domestic Unit Value and Entry of Multi-Product Plants into Export Markets, Mimeo, University of Sussex.

Jovanovic, B., 1982. Selection and the evolution of industry. Econometrica 50 (3), 649-670.

Kugler, M., Verhoogen, E., 2008. The Quality-Complementarity Hypothesis: Theory and Evidence from Colombia. NBER Working Paper No. 14418.

Lileeva, A., Trefler, D., 2007. Improved Access to Foreign Markets Raises Plant-Level Productivity... For Some Plants. NBER Working Paper No. W13297.

Roberts, M., Tybout, R., 1997. The decision to export in Colombia: an empirical model of entry with sunk costs. American Economic Review 87 (4), 545-564.

Salomon, R., Shaver, J.M., 2005. Learning-by-exporting: new insights from examining firm innovation. Journal of Economics and Management Strategy 14 (2), 431-461.

Shaver, J.M., 2007. The Benefits of Geographic Sales Diversification: How Exporting Facilitates Capital Investment. Working paper, Carlson School of Management.

Syverson, C., 2010. What determines productivity? NBER Working Paper No. 15712.

Van Biesebroeck, J., 2007. Robustness of productivity estimates. Journal of Industrial Economics 55 (3), 529-569.

Vernon, R., 1966. International investment and international trade in the product cycle. Quarterly Journal of Economics LXXX, 190-207. 